\title{
General Development Strategies
}

Having briefly described the high country in terms of its environment, potential pasture production, and suitability of particular pasture species, we need to consider development strategies for sustainable animal production. Important points are:

- Type of animal

- Provision of winter feed

- Land and management requirements to grow young stock

- Subdivision of land into its various natural units to fulfil the year round stock feed requirements

- Efficient use of fertilisers

- General strategies of pasture development using legumes, grasses and nutrient cycling.

\section{Type Of Animal}

At present the options for the type of domesticated herbivorous animal to farm in the high country are sheep, cattle, deer or goats. There is also the unwelcome competition from feral herbivores such as rabbits, hares, deer, goats, chamois and thar. Each of the domesticated and feral species has environmental preferences and constraints, similar to those described for pasture species.

Sheep are suited to the widest range of conditions from the high alpine areas to the undeveloped low altitude semi-arid zones, and to developed pastures in all areas. The average high country run has about 8,700 sheep. At the environmental extreme of both the cold, wet higher altitudes, and the semi-arid areas, the merino-is-the-bestadapted-of-the-sheep-breeds:

Wool is the main source of income for runs in those zones. It is fortunate that the breed that is adapted to these environments is the one producing the more profitable fine wool. In the high rainfall and snow risk zones, particularly the gorge runs, a Merino with clean face and legs and a dense, fleece is preferred. By contrast, in the drier zones a well covered higher yielding Merino has advantages.

With the higher pasture production from developed areas, there are the options of wool, store sheep, and even fat lamb production using
Merino, crossbred and other breeds. This has the advantage of diversifying run income.

Most runs have some cattle. Their grazing is generally associated with low altitude moist terrain or swampy areas. Winter feed is more critical for cattle than sheep. Farm economics have generally favoured sheep production over beef production. There was a period in the 1950s when cattle production was encouraged relative to sheep production for soil conservation reasons. This was later revised when it was realised that cattle damage to the wetlands and the stream edges had a greater effect on flooding than the sheep grazing on vegetation at a higher altitude. Cattle have a role for scrub, bracken and silver tussock control in some of the higher rainfall areas.

The main pest scourge of the high country is the feral rabbit as shown by their most recent plague and the associated Rabbit and Land Management Programme over the last decade. Feral rabbits are the main source of feed competition with domestic stock, with the competition being greatest in the warm, moderate to semi-arid undeveloped zone. The rabbit problem clearly illustrates the point that vegetation and nutrient sustainability is determined by the total grazing pressure, not just that of domestic stock, and that as a consequence, if pests increase, domestic stock have to be decreased.

Red deer in their feral state were most prevalent in the higher rainfall areas in the transition zone between forest, scrublands and tussock grasslands. However, during the initial decade of their domestication, their high economic value and legal fencing requirement resulted in their being concentrated on a few runs, generally on developed pastures on easy terrain.

Feral goats are relatively rare in the high country now, but there was a brief period of domestication, primarily for control of briar and for fibre production. The trend is for their use in the moderate to low rainfall undeveloped pastures.

Hares give some competition over a wide range of environments; deer near the scrub and forest margins; and chamois and thar give slight competition only at the highest altitudes. 


\section{Winter Feed}

Lack of winter feed for stock is the main constraint to pastoral farming in the high country. The management of a high country run revolves around the extent and management of areas suitable for providing winter feed.

Various winter feed options include summer saved native pasture, summer saved legume pasture; summer saved grass/legume mixtures, nitrogen fertilised grass; hay or silage, and special purpose winter crops. Except for the native pasture, the other options imply pasture development to different levels of intensity. All are special purpose pastures.

The traditional summer saved native country for wintering stock was low altitude sunny country, sloping rather than flat, from which snow would clear first following a storm. The same type of country would be preferred also for winter feeding-out when using the other options. The winter country, because of its topography and aspect, will tend to have good spring pasture growth but be summer dry.

The various pasture options for providing winter feed differ in their cost. While the hay or silage options from spring and early summer harvests, will be the most expensive generally, they do have the advantage that for winter feed their quantities are known well in advance of their time of use. All the other options are very dependant on growth conditions in the autumn only shortly before their requirement time.

Young stock and rams have priority for winter feed. Many runs will supplement ewes, and only a small proportion of runs will supplement wethers. In the high country, winter feeding can only hope to maintain animal body weights or minimise losses. Stock weight gains are unlikely over winter.

\section{Young Stock}

A major consideration in management of a high country run is whether the land and its pasture is suitable for breeding replacements and growing young stock. A few runs have to buy in all their replacement stock.

Wool is the major produce of most runs, and there may be a need to only carry sufficient ewes to breed for replacement. Autumn flushing of ewes, while desirable, is not as prominent as in lowland fat lamb producing areas. There is a desirable trend towards providing better winter nutrition of ewes, particularly towards the later stages of pregnancy. Lambing generally takes place in September - October to coincide with spring growth.

Young stock should have feed priority from lambing to weaning in January or February and during their first winter. Special purpose blocks and pastures are needed to feed young stock. Runholders value the lower, warm or sweet country for this purpose. It is this country that generally has drier recent soils which are less weathered than those which are wetter or at higher altitudes. There are many similarities between winter country and lambing or hogget country. Where such land is limited, careful planning and management is needed to get the best use, rather than abuse, of this land.

\section{Subdivision}

Ideally, the different landscape units within a run should be managed separately, for they will differ in potential pasture growth, in the ideal spelling time to allow adequate regrowth, and in the stocking rates needed to ensure sustainable use. However, in practice, for both physical and financial reasons, this ideal is generally not achievable. The following approach to subdivision is suggested.

First, mark in the boundaries between landscape units of different types e.g. on a land capability map or aerial photograph (Figure 2, page 5). If any of these units are still greater than 100ha, then consider further subdivision, preferably along the contour, as animals tend to move and graze horizontally rather than up and down the hill. Some adjacent areas may need to be combined if they are less than 20ha each. Next, mark out possible access lanes. These should be at least $50-100 \mathrm{~m}$ wide and should be regarded as narrow paddocks. Make line adjustments if necessary to facilitate easy stock movement and to prevent acute comers to paddocks.

The result is a map of potential fence lines that may be achieved at some time in the future (Figure 2c). Using this map, start subdivision in blocks needed for special purpose pastures, or where development is intended, or where present utilisation is most uneven. This is where grazing control is most needed. Clearly, the ideal block size will vary according to the intended size of the mob and its specific feed requirements.

It may not always be necessary to use fencing to manage utilisation. Recent work has indicated that partial development of large blocks can alter the use of the whole block. In particular, 
the development of lower slopes and valley bottoms can lessen the grazing pressure on the high slopes.

There are divergent views on the need for stock water. Some insist on a continuous supply of clean water in all paddocks. While others consider water unnecessary so long as adequate feed is available. They point to third generation flocks that have never seen water, or animal behaviour studies where sheep were observed not to drink on dry tussock country in midsummer even though water was available. Lack of stock water should not be regarded as a constraint in high country development and subdivision.

\section{Pasture Development}

One of the main avenues for improving animal production in the high country is pasture development. The large holding and block sizes have traditionally encouraged large scale development. There are numerous examples of areas which have been oversown at great cost but never effectively used or maintained $\boldsymbol{\bullet}$ let alone ever paid for themselves. Oversowing tends to increase the difference between summer and winter feed supply.

Clearly, individual runholders must identify the periods when feed is most limiting to their stock and act accordingly. Each piece of development should be considered as a special purpose pasture, done to satisfy particular stock feed requirements. This approach has the advantage that one will then consider smaller areas, and the consequent fencing, ground preparation and management that should go with them. A large number of such special purpose paddocks may be needed.

If additional feed is required for winter and spring, then lower, sunny slopes or flats should be considered for development because of their warmer temperatures. By contrast, if more autumn feed is required, 't' ${ }^{\prime}$ ' will' be necessary to choose sites which still have adequate moisture at that time of the year. Note that in dry areas shady aspects are generally more productive than sunny aspects, while in higher and wetter areas, where temperature is the major limitation to pasture growth, sunny faces are more productive.

\section{Fertilisers}

The main input needed in pasture development is fertiliser. For the high country it is always likely to be costly because of the high transport component. Against this disadvantage, is the advantage that because much of the developable high country is in the moderate to low rainfall zone, that the rates required are not as high as in the higher rainfall areas elsewhere in New Zealand.

Fertiliser responses show a diminishing return with application rate, with the greatest response at low application rates. Taken in conjunction with the fact that developable land as such is seldom a limiting factor in the high country, then a better development strategy may be to use a given affordable amount of fertiliser at a lower rate over a larger area. The associated requirement is that the legume and grass species used in the development should be matched closely with the actual fertiliser rates used, and that there needs to be the associated subdivision or animal control to efficiently use the resulting enhanced pasture growth.

\section{Legumes}

For most of the high country, pasture legumes have a major competitive advantage over grasses through their capability to fix their own nitrogen. Fixation should not be assumed. Nitrogen fixation is totally dependent on rhizobia bacteria associated with the roots of legumes, so inoculation of legume seed with an effective rhizobia strain is as important as sowing the seed. The rate of nitrogen fixation under adequate phosphorus and sulphur fertiliser levels is determined mostly by legume growth and is largely independent of species. Thus the choice of legume should be determined largely by the species which grows best in the particular situation.

Because of the low growth rates of plants and slow mineralisation of organic matter due to the low mean temperature, the build up of total soil organic matter and nitrogen is slow. It may be many years before the stage is reached where the_introduced grasses_have both the necessary nitrogen levels and competitive advantage. Improved high country pastures can therefore remain legume dominant for many years.

Even under high fertiliser levels, for high growth rates of alsike, white, and red clover, or luceme, typically 4-5 years may elapse after initial development before introduced grasses make a significant contribution to the pasture. For moderate fertiliser inputs and associated legumes, like alsike clover, lotus, birdsfoot trefoil and perennial lupin, it may be many years before soil nitrogen levels are adequate for grasses like cocksfoot, timothy, tall oat grass or 
tall fescue. The period may be of the order of 20 years or more for low fertiliser input and low production legumes like zigzag clover.

The volunteer grasses like browntop and sweet vernal usually make up the major proportion of the grass component in many development situations. These are all valid options, but in high country farming, as in life in general, you only get what you are willing to pay for. In pasture production terms, this generally means the amount of fertiliser used to grow legumes.

\section{Grasses}

The low initial fertility, and the long clover dominant stage of many grassland developments, leads to a debate on whether to include grasses in the initial sowings. Even though grasses should ultimately be more important because of their greater winter feeding quality and cold tolerance, their initial establishment is variable.

They can be sown successfully in the fully cultivated situation, though, even there, their contribution can be low for several years. The establishment of grasses by aerial oversowing is difficult, especially if there are constraints of limited moisture or excessive competition.

Cocksfoot and ryegrass can be established if conditions are favourable and, given tune, may dominate feed production on drier country where browntop is absent and once soil nitrogen levels have been increased.

\section{Nutrient Cycling}

Grazing animals derive their mineral mainly from the pasture, though some can come from direct ingestion of soil.

Pasture plants derive their nutrients from the soil solution, which in turn, can come from direct fertiliser application, weathering of rocks, or more usually from the mineralisation of litter and soil organic matters. This soil organic matter is the main nutrient reserve and buffer in the nutrient cycle.

Like a bank, the release or payout can be of capital, or the more sustainable method as interest, so that the return from either at least equals that used to achieve the initial pasture growth.

Nitrogen is generally the most deficient nutrient for pastures. In New Zealand this deficit is rectified by growing legumes to fix nitrogen. Nitrogen release to the soil is achieved through the rapid animal excreta pathway, or more slowly through mineralisation of organic matter. While the former pathway is faster, the return of nutrients is not so even and they tend to be concentrated in stock camp areas.

By the analogy of a bank and a commercial economy, as used above, it is not clear whether it is better to leave all the nutrients locked up in organic matter, or have all the nutrients in circulation, with a consequent buoyant economy of plant growth, but the associated risk of reserves being lost in the system, and outbreaks of bankruptcy!

The original tussock grasslands were a good example of a very conservative economy, with the large capital of nutrients locked up, like trees, in large amounts of standing dead biomass, which was released only slowly.

The grazing and burning of the "past pastoral phase mainly used that capital, though to put it in the total New Zealand context, that use lasted a century and a half in the high country, as compared with only half a century following pastoral development on burnt forest areas of the North Island.

High country pastoral farming is now reaching the stage, as elsewhere in New Zealand, that for sustainability, the mineral removal in products must be more than balanced by added fertiliser.

In the management of nutrient cycling, there are a number of compromises between the safe but slow release characteristics of nutrients stored in organic matter; versus the more rapid turnover and availability of nutrients, through release by animal dung and urine into soil solution. There is potentially a risk of loss with the latter method too. The general trend is that as productivity and nutrient turnover increase, the risk of loss increases. 